\title{
The Seven Ages of Man
}

Poem lyrics of Seven Ages Of Man by William Shakespeare.

All the world's a stage,

And all the men and women merely players,

They have their exits and entrances,

And one man in his time plays many parts,

His acts being seven ages. At first the infant,

Mewling and puking in the nurse's arms.

Then, the whining schoolboy with his satchel

And shining morning face, creeping like snail

Unwillingly to school. And then the lover,

Sighing like furnace, with a woeful ballad

Made to his mistress' eyebrow. Then a soldier,

Full of strange oaths, and bearded like the pard,

Jealous in honour, sudden, and quick in quarrel,

Seeking the bubble reputation

Even in the cannon's mouth. And then the justice

In fair round belly, with good capon lin'd,

With eyes severe, and beard of formal cut,

Full of wise saws, and modern instances,

And so he plays his part. The sixth age shifts

Into the lean and slipper'd pantaloon,

With spectacles on nose, and pouch on side,

His youthful hose well sav'd, a world too wide,

For his shrunk shank, and his big manly voice,

Turning again towards childish treble, pipes

And whistles in his sound. Last scene of all,

That ends this strange eventful history,

Is second childishness and mere oblivion,

Sans teeth, sans eyes, sans taste, sans everything. 